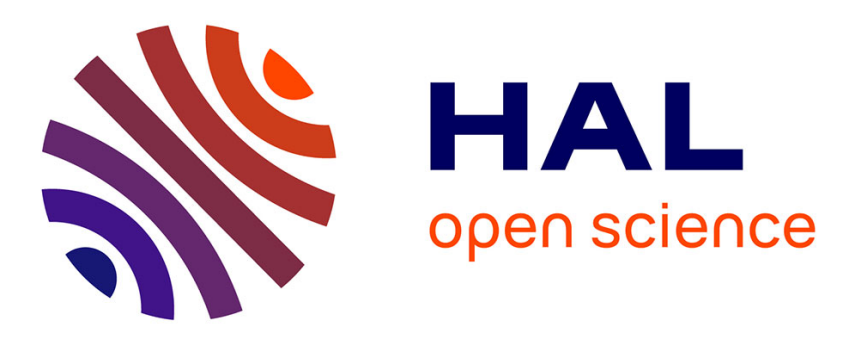

\title{
Experimental Parametric Study of Suffusion and Backward Erosion
}

\author{
Fateh Bendahmane, Didier Marot, Alain Alexis
}

\section{To cite this version:}

Fateh Bendahmane, Didier Marot, Alain Alexis. Experimental Parametric Study of Suffusion and Backward Erosion. Journal of Geotechnical and Geoenvironmental Engineering, 2008, 134 (1), pp.5767. 10.1061/(ASCE)1090-0241(2008)134:1(57) . hal-01006849

\section{HAL Id: hal-01006849 \\ https://hal.science/hal-01006849}

Submitted on 13 Dec 2017

HAL is a multi-disciplinary open access archive for the deposit and dissemination of scientific research documents, whether they are published or not. The documents may come from teaching and research institutions in France or abroad, or from public or private research centers.
L'archive ouverte pluridisciplinaire HAL, est destinée au dépôt et à la diffusion de documents scientifiques de niveau recherche, publiés ou non, émanant des établissements d'enseignement et de recherche français ou étrangers, des laboratoires publics ou privés. 


\title{
Experimental Parametric Study of Suffusion and Backward Erosion
}

\author{
Fateh Bendahmane ${ }^{1}$; Didier Marot ${ }^{2}$; and Alain Alexis ${ }^{3}$
}

\begin{abstract}
Within hydraulic earth structures (dikes, levees, or dams), internal seepage flows can generate the entrainment of the soil grains. Grain transportation affects both particle size distributions and porosity, and changes the mechanical and hydraulic characteristics of the earth's structure. The occurrence of failures in new earth structures due to internal erosion demonstrates the urgency of improving our knowledge of these phenomena of erosion. With this intention, a new experimental device has been developed that can apply hydraulic stresses to reconstituted consolidated cohesive soils without cracks in order to characterize the erosion evolution processes that might be present. A parametric study was conducted to examine the influence of three critical parameters on clay and sand erosion mechanisms. When the hydraulic gradient was low, it was concluded that the erosion of the structure's clay fraction was due to suffusion. When the hydraulic gradient increased, it was concluded that the sand fraction erosion initiation was due to backward erosion. The extent of the erosion was dependent on the clay content. The study underlines the complexity of confinement stress effects on both erosion phenomena.
\end{abstract}

Keywords: Erosion; Triaxial stress; Cohesive soils; Soil structure; Hydraulic structures.

\section{Introduction}

The presence of water in earth structures, such as dams and dikes, may cause damage by three mechanisms: Sliding, overtopping, and internal erosion. Internal erosion appears to be one of the main causes of failures and damage to embankment dams. Among 11,192 surveyed dams (Foster et al. 2000), 136 show dysfunctions, which are divided up as $5.5 \%$ related to sliding, $48 \%$ related to overtopping, and $46 \%$ related to internal erosion. Hence, internal erosion appears to be a main cause of observed instabilities.

Internal erosion is due to the transport and migration, under the action of flow, of particles constituting the soil within the earth's structure. Improvements in understanding internal erosion mechanisms are hindered by the complexity of these mechanism and the difficulties associated with their detection. When internal erosion occurs, the hydraulic and mechanical characteristics of the soil are altered. The material permeability, for instance, may undergo sharp changes that may cause loss of water tightness of

\footnotetext{
${ }^{1}$ Postdoctoral Student, Institut de Recherche en Génie Civil et Mécanique GeM, UMR CNRS 6183, Université de Nantes, BP 420, 44606 Saint-Nazaire Cedex, France.

${ }^{2}$ Associate Professor, Institut de Recherche en Génie Civil et Mécanique GeM, UMR CNRS 6183, Université de Nantes, BP 420, 44606 Saint-Nazaire Cedex, France. E-mail: didier.marot@univ.nantes.fr

${ }^{3}$ Professor, Institut de Recherche en Génie Civil et Mécanique GeM, UMR CNRS 6183, Université de Nantes, BP 420, 44606 Saint-Nazaire Cedex, France.
}

the structure or lead to increases in pore pressure, which may be prejudicial to the stability of the slopes of the structure.

Internal erosion mechanisms involve many parameters, some of which are coupled. Laboratory testing to identify specific mechanisms are easier to carry out than monitoring full scale structures. Laboratory tests allow for differences in interpretation within the same test campaign; Skempton and Brogan (1994) explained the piping of fine grains by the presence of a coarse grain framework that carried the greater part of the overburden load, whereas Monnet (1998) defined a piping critical gradient for the whole soil.

The two main phenomena responsible for erosion of particles in soils that are not cracked are backward erosion and suffusion. In backward erosion, particles are detached from the downstream surface of the structure by the seepage forces in the soil. In suffusion, the process is similar, but the coarse particles form a matrix and erosion is only of the finer particles in the pore space between the larger particles.

Different criteria to assess initiation and development of internal erosion are proposed in the literature. The different approaches mostly rest on the analysis of the material particle size or on the estimation of the erosion critical hydraulic gradient. These criteria, which are mostly determined for cohesionless soils, are summarized below.

\section{Granulometric Criteria}

On the assumption that bigger grains can hinder the erosion of smaller grains, Kenney and Lau (1985) have developed a method for assessing whether soils are internally unstable based on the shape of the grading curve. This has been validated for both up and down flows (Monnet 1998; Skempton and Brogan 1994). The recognized limits of these prediction criteria may come from the lack of consideration of porosity and soil confinement stresses. The methods also do not apply to clay soils. 


\section{Hydraulic Criteria}

In order to characterize the initiation of backward erosion, several authors have developed expressions that relate to the critical hydraulic gradient. Some of them are strongly dependent on the specific configuration studied and, therefore, cannot be applied generally. Because of the importance of the uncertainties in the expressions based on the hydraulic gradient, engineers prefer to choose high values (up to 15) for the safety factor on the critical gradient for sand boils.

In order to take into account the characteristics of cohesive soils (Khilar et al. 1985), the erosion critical gradient is expressed as a function of the hydraulic shear stress $\tau$, of the soil, the intrinsic permeability $K$, and the porosity $n$. The main difficulty and interest when using this approach lies in the determination of $\tau$, which is dependent on both clay mineralogy and pore fluid properties (Arulanandan and Perry 1983). For example, to characterize the initiation of internal erosion, Reddi et al. (2000) have developed an expression of the shear stress $\tau$ for cohesive soils

$$
\tau=\left(\frac{\Delta P}{\Delta L}\right) \sqrt{\frac{2 K}{n}}
$$

with $\Delta P=$ pressure drop $(\mathrm{Pa}) ; \Delta L=$ sample height $(\mathrm{m}) ; \Delta P / \Delta L$ =average pressure gradient $\left(\mathrm{kN} / \mathrm{m}^{3}\right) ; n=$ porosity; and $K=$ intrinsic permeability $\left(\mathrm{m}^{2}\right)$, determined by

$$
K=k \frac{\eta}{\gamma_{w}}
$$

with $k=$ hydraulic Darcy's permeability $(\mathrm{m} / \mathrm{s}) ; \eta=$ dynamic viscosity $\left(\mathrm{kg} \mathrm{m}^{-1} \mathrm{~s}^{-1}\right)$; and $\gamma_{w}=$ volumic weight of water $\left(\mathrm{kN} / \mathrm{m}^{3}\right)$.

The migration of particles within the soil, when internal erosion begins, may rapidly cause dysfunctions at the level of the whole structure. The characterization of the soil mechanical performance of soils is strongly linked to the fluid/soil interaction. The soil's stress field also conditions its behavior. However, the influence of stresses on internal erosion mechanisms within materials is not clear. Tomlinson and Vaid (2000), who have examined the effect of confining pressure on internal erosion of an artificial material (glass balls), conclude that the effects are minor. Wan and Fell (2004) showed that the degree of compaction had an effect on the rate of erosion of silty and cohesive natural soils, but that effect is superimposed on the effect of water content, and hence, degree of saturation. Papamichos et al. (2001) have shown that initiation of erosion in sand is a function of loads, and that beyond a certain threshold erosion sharply increases.

Soil structure can be broken down into two groups: A primary structure and a secondary structure (Kenney and Lau 1985; Barakat 1991; Lafleur et al. 1989; Tomlinson and Vaid 2000). The primary structure consists of grains, which are in contact with each other and provide primary resistance to erosion, compressibility, and shear strength. If these grains are eroded, there are changes to the soil resistance, and these changes may cause collapses. The secondary structure, on the other hand, is composed of grains that are in the spaces between the primary grains and may be displaced under the action of mechanical (vibration) or hydraulic (flow) stresses. Barakat (1991) concludes that erosion of these secondary particles in a process of suffusion does not affect soil mechanical slope stability. It, however, may modify the settlement potential of cohesive soils according to Ayadat et al. (1998).

Current internal erosion criteria do not adequately consider the hydraulic/mechanical coupling and the simultaneous influence and interactions of the main parameters that appear to influence erosion (porosity, grain size, confining stress, gradient). The great number of parameters affecting the different phenomena, as well as their interrelated features, emphasize the importance of experimental studies that can provide greater insight into erosion processes.

\section{Design of New Device}

\section{Main Characteristics}

The experimental device developed by the authors, which can be used to study the initiation of internal erosion, was developed for sandy-clay samples.

In order to reduce parasitic flows between a soil sample and a rigid cell wall, Kenney and Lau (1985) introduced a rubberlike diaphragm between the rigid wall and the compacted sample. As an alternative, Daniel et al. (1984) developed a permeameter using a modified triaxial cell. This flexible wall permeameter offers the potential for more complete control over stresses that act on the soil specimen, and is better suited for minimizing side wall leakage. Because of these advantages, the new device, which is placed in a temperature-controlled chamber $\left(20 \pm 0.5^{\circ} \mathrm{C}\right)$, consists of three modified triaxial cells that are coupled to two air-water cells. The whole device is designed to allow flows through the samples within the cells. So as to avoid all unwanted disturbances on the samples, saturation, consolidation, hydraulic, and mechanical test stages are carried out inside the test cell without deconfining the sample. The detection of erosion in the effluent is performed using optical aids and by weighing the amount of grains in the eroding fluid (Fig. 1).

The three triaxial cells allow for saturation, consolidation, and the characterization of volume change and deformations. These cells can be used simultaneously in order to saturate and to consolidate three samples together, and thus to minimize the test program's duration. They have been modified to let fluids flow through the samples with limited head losses, and discharge fine particles washed away by the process without clogging the drainage system (Fig. 2). The fluid is circulated into the top of the sample using a $22 \mathrm{~mm}$ thick layer of glass sphere to diffuse the fluid on the sample contact interface uniformly. At the bottom of the sample, the funnel-shaped draining system is specially designed to avoid clogging or the formation of a layer of particles within the collection system. This makes it possible to use different filters, which can be either granular or made of geotextiles with openings ranging between $1 \mu \mathrm{m}$ and $8 \mathrm{~mm}$ and with a maximum thickness of $17 \mathrm{~mm}$. For suffusion and backward erosion tests on sandy-clay samples, a $4 \mathrm{~mm}$ pore opening grid is used to survey the migration of all the particles (sand and clay). The cell outlet is linked to an effluent tank through a transparent drainage pipe.

The hydraulic system consists of different elements generating pressures and suctions, all connected to an 80 valve panel board, which can operate on the three triaxial cells simultaneously. The system includes two pressure volume controllers, one for the injection and the other to generate sample predetermined confining pressures. Both controllers are continuously weighed during the tests to determine both injected flow rates and sample volume changes. The pressure inside these cells cannot exceed $70 \mathrm{kPa}$ (Fig. 3).

The new device also includes three pressure regulators connected to air/water interface cylinders, which are used to generate 


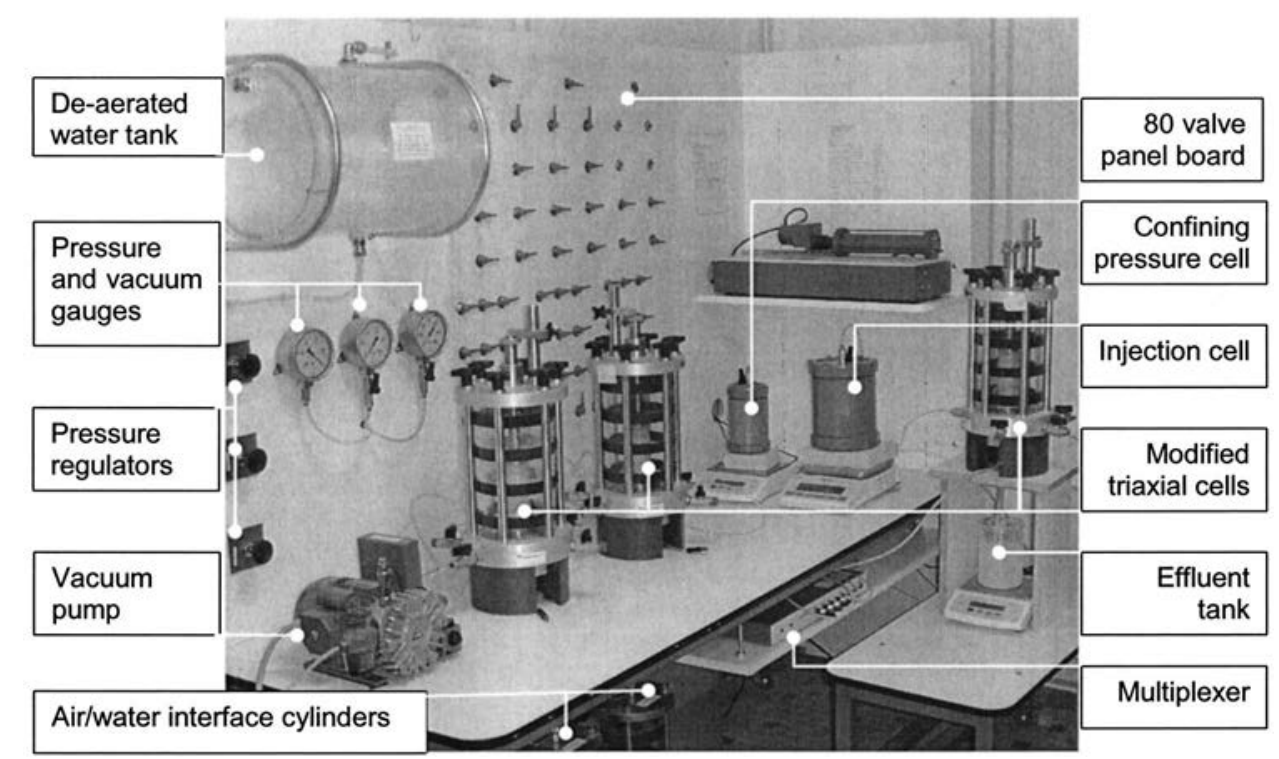

Fig. 1. Photograph of the experimental device

and maintain constant pressures. The injected fluid is kept in a tank, from where air bubbles are removed using a $90 \mathrm{kPa}$ vacuum pump.

Two pressure gauges $(250$ and $600 \mathrm{kPa})$ and a vacuum gauge $(-100 \mathrm{kPa})$, connected to the valve panel board, are used to carry out measurements throughout the whole circuit. A pressure gauge is connected at the cell outlet to measure the pore pressure during the sample consolidation phase or the fluid outlet pressure.

In order to study the very beginning of internal erosion, to detect the possible initiation point, and to carry out real-time measurements of the eroded clay quantity, a photo sensor has been developed (this device is able to measure only the small

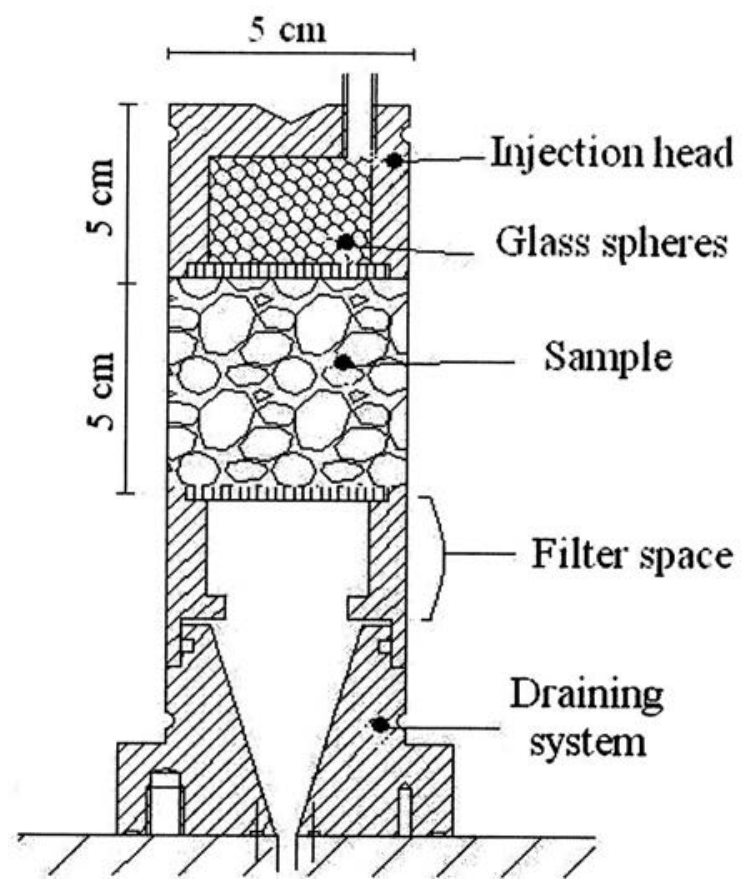

Fig. 2. Schematic diagram of a triaxial cell quantities of eroded material). Placed on the pipe connecting the triaxial cell to the effluent tank, it measures the transparency of the fluid coming through the pipe. Thanks to a previous calibration for different kaolinite erosive mass rates, the optical sensor can quantify very small quantities of eroded material. Fig. 4 represents the instantaneous kaolinite content versus the relative variation of the optical sensor terminal voltage.

The instantaneous kaolinite content determined by the optical sensor is expressed in the form

$$
S_{\text {opt }}(t)=\frac{\Delta m_{k \text { out }}}{\Delta m_{w \text { out }}}
$$

with $m_{k \text { out }}=$ kaolinite mass within the effluent; and $m_{w \text { out }}=$ water mass within the effluent.

The injection rate $q_{w}$ is defined by

$$
q_{w}(t)=\frac{\Delta m_{w \text { inj }}(t)}{\Delta t}=\frac{\Delta m_{w \text { out }}(t)}{\Delta t}-\frac{\Delta m_{w \text { sam }}(t)}{\Delta t}
$$

with $m_{w}$ inj $=$ injected water mass; and $m_{w}$ sam $=$ water mass within the sample.

Regarding clay erosion, the water mass change inside the sample $\left(\Delta m_{w \text { sam }}\right)$ can be neglected in comparison with the injected water mass change. We then obtain the erosive mass rate per unit surface as

$$
q_{s}(t)=\frac{S_{\mathrm{opt}}(t) \times q_{w}(t)}{s}
$$

with $s=$ sample cross-sectional area $\left(\mathrm{m}^{2}\right)$.

The integration of the erosive mass rate with time gives the cumulated eroded solid mass during the tests, that is

$$
m(t)=\int_{0}^{t} s \times q_{s}(t) d t
$$

In the case of sand erosion, the high quantities of eroded material allow us to use mass measurements. Thanks to these mass measurements, the rate of sand and clay erosion can be calculated.

Cohesive soil testing usually takes a long time, so automation of the operations is provided using a multiplexer that collects 


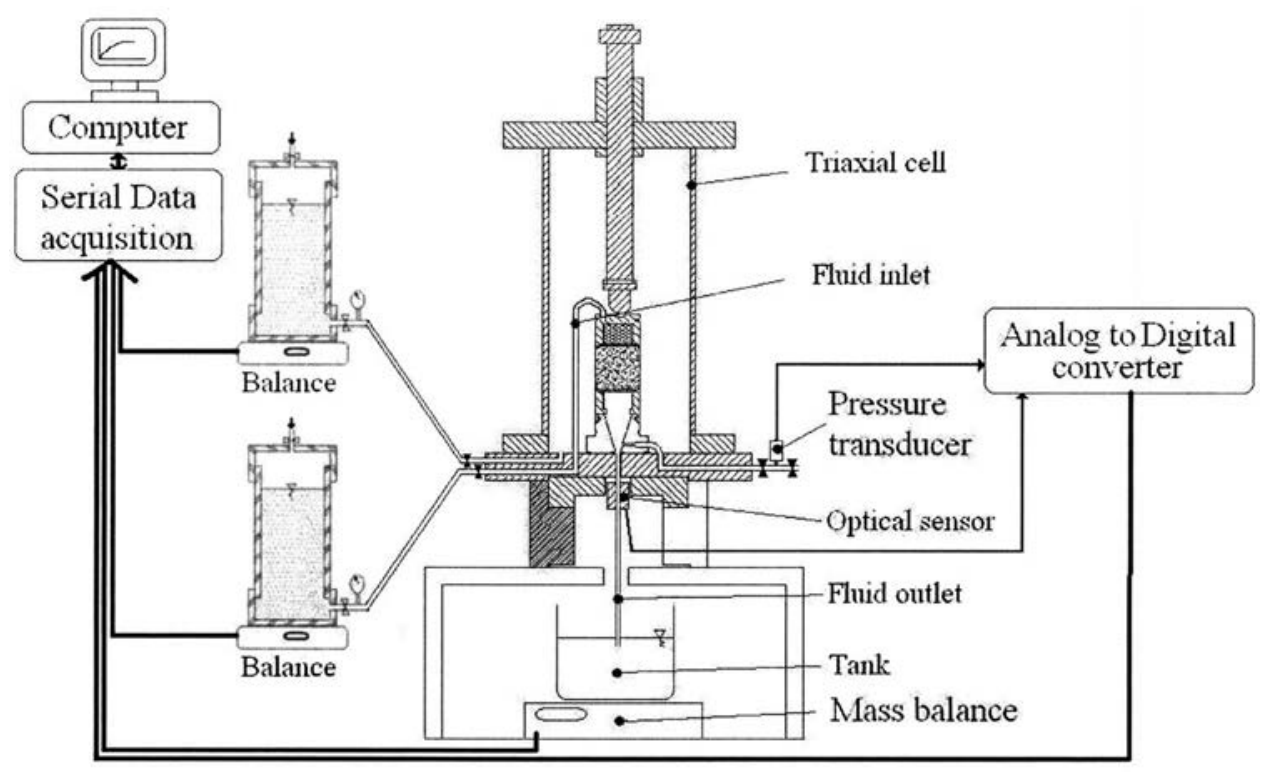

Fig. 3. Schematic representation of the experimental triaxial cell equipped with the two controllers, effluent weight measurement, and optical sensor mechanism

analog signals from the gauges and digital signals from both the pressure/volume controllers and the electronic scales. The multiplexer is connected to a dedicated computer, which operates the acquisition of the data and the monitoring of the tests thanks to a specific visual basic piece of software developed by the authors.

\section{Test Procedure}

The material used is a washed Loire sand (grain density: $26 \mathrm{kN} / \mathrm{m}^{3}$ ) with a grain size distribution within the range $80 \mu \mathrm{m}-1 \mathrm{~mm}\left(d_{50}=440 \mu \mathrm{m}\right.$, uniformity coefficient: 3.125$)$. The clay consists of kaolinite, with liquidity and plasticity limits of 55 and $22 \%$, respectively. Fig. 5 presents the grain size distributions of both the sand and the clay. The preparation phase is divided into three steps: Production and installation of the sample, saturation, and then consolidation. The repeatability of the production is achieved by the following procedure. The sand is first mixed with a moisture content of $8 \%$. While mixing continues, powder clay is then progressively added and mixing is then carried on for an additional $10 \mathrm{~min}$. This method has been validated through confirmation of the size distribution homogeneity achieved after mixing (Bendahmane 2005).

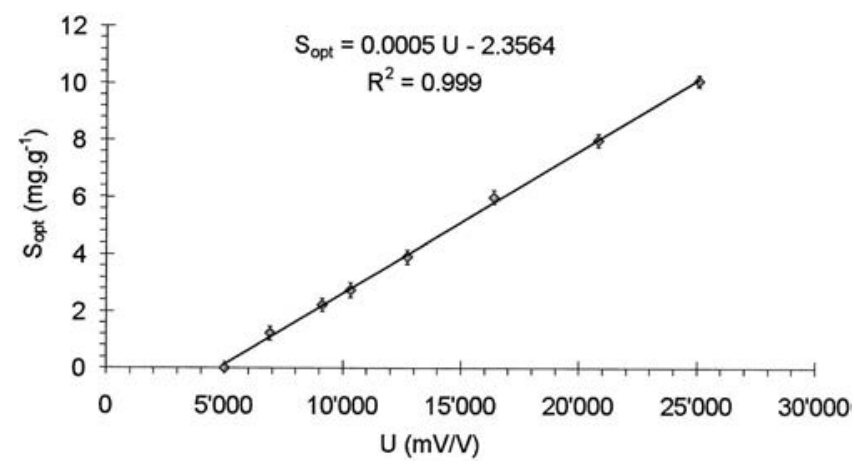

Fig. 4. Optical sensor calibration curve for different kaolinite contents
The installation of the sample inside the cell requires preliminary forming. The study conducted by Camapum De Carvalho et al. (1987) to examine how compaction methods affect a cohesive soil's homogeneity reveals that semistatic compaction proves to be the best method to achieve homogeneous samples. The next best method these authors advocate is single layer semistatic compaction within a mold using two pistons. In conformity with the results of this study, we use a $50 \mathrm{~mm}$ diam and $50 \mathrm{~mm}$ high mold under the action of two pistons, until the initial fixed dry density (before consolidation) is reached. This initial dry density value $\left(17 \mathrm{kN} / \mathrm{m}^{3}\right)$ is lower than the smallest value reached after consolidation.

The saturation phase begins when a small $20 \mathrm{kPa}$ confinement pressure is applied to prevent any parasitic leakage between the sample and the diaphragm. In such sand clay mixtures, saturation with only deaerated water is not effective (final saturation ratio: About 90\%). Consequently, some carbon dioxide is initially injected into the sample starting at the bottom, before saturation is completed using demineralized and deaerated water. The whole saturation phase requires approximately $24 \mathrm{hr}$.

The confining pressure increases in steps in conformity with standard AFNOR NFP 94-074 (AFNOR 1994) procedures. In order to control the quality of the sample consolidation, expelled

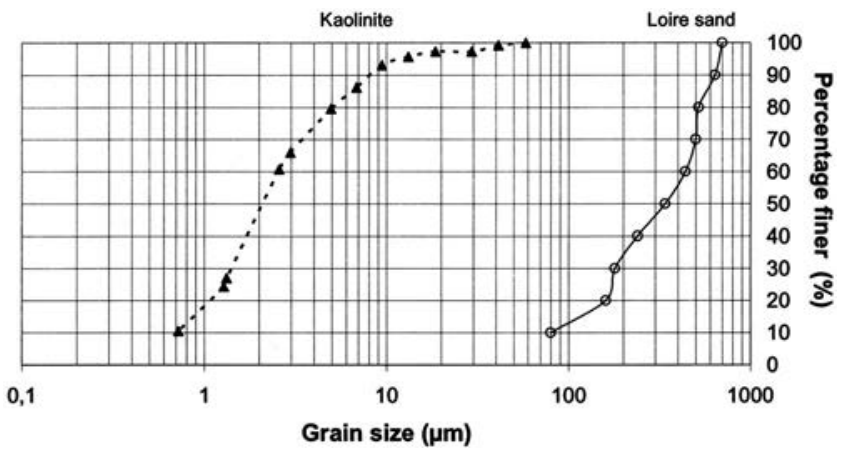

Fig. 5. Grain size distributions of sand and clay 
fluid volume measurements are performed until stabilization [in conformity with standard AFNOR NFP 94-074 (AFNOR 1994) procedures] and the excess pore pressure dissipation is checked. The confining pressure is finally decreased by half to avoid further consolidation of the material because of the inflow. Last, the sample is subjected to a hydraulic action in downward direction using demineralized and deaerated water in order to keep the injected fluid characteristics identical.

\section{Details of Tests and Analyses of Results}

\section{Test Principle}

Three parameters (hydraulic gradient, clay content, and confining pressure) with the following characteristics have been examined using the new device:

- Kaolinite content: 5, 10, 20, and 30\%;

- Hydraulic gradient ranging between 5 and $160 \mathrm{~m} / \mathrm{m}$; and

- Isotropic confining pressure $\sigma_{3}\left(\sigma_{1}=\sigma_{3}\right): 100,150,200$, and $250 \mathrm{kPa}$.

The range of hydraulic gradients was chosen to be relatively large in order to include the possible reduction of flow path in an earth structure by backward erosion phenomena. In this case, the local gradient can be much higher than the global one.

The highest confining pressure is equivalent to the earth pressure, which exits at $12.5 \mathrm{~m}$ depth in a typical earth dam. The details of the experimental program, which consisted of 30 tests, are presented in Table 1.

In order to improve understanding of the erosion phenomena, a distinction is made between the tests during which only clay particle migration is initiated, and the tests during which the transport of both clay particles and sand grains is observed. Maximum erosion rates per sample cross section are preferred as a measurement indication to cumulative eroded mass information, because the erosion rate for the condition investigated here reaches its maximum value very quickly, which, therefore, means that it does not depend on the test length.

\section{Clay Erosion}

Fig. 6 shows that the internal erosion occurs when a $60 \mathrm{~mm}^{-1}$ hydraulic gradient is applied, but not with a $5 \mathrm{~mm}^{-1}$ hydraulic gradient. Because the amount of eroded particles was too small to be weighed, the optical sensor, calibrated for kaolinite, was used for the clay erosion tests. From the beginning of the test, the mass flow given by the optical sensor increased until reaching a maximum value $q_{s}$ max. It then decreased sharply, to finally end with an asymptotic behavior toward zero.

When erosion is nonexistent, the permeability remained constant. It, however, decreased by a factor of 10 during the tests where erosion was initiated. Consequently, according to the previously defined terminology, this phenomenon, characterized by some diffuse mass losses, can be called suffusion. In our tests, suffusion induces a clogging in the soil specimen. The tests show that the higher the hydraulic gradient, the bigger the mass of eroded clay. Fig. 7 represents the maximum erosion rate versus gradient curve (for a soil with a $10 \%$ kaolinite content and $200 \mathrm{kPa}$ confining pressure).

The results of the three tests, carried out with identical parameter values $\left(i=20 \mathrm{~m} / \mathrm{m}, 10 \%\right.$ clay content, $\left.\sigma_{3}=200 \mathrm{kPa}\right)$, demonstrate the good repeatability of the tests. The measurements show that this erosion phenomenon can be considered
Table 1. Main Characteristics of the Tests

\begin{tabular}{|c|c|c|c|}
\hline $\begin{array}{l}\text { Number } \\
\text { of sample }\end{array}$ & $\begin{array}{c}\text { Percentage } \\
\text { of clay } \\
(\%)\end{array}$ & $\begin{array}{c}\text { Confining } \\
\text { pressure } \\
(\mathrm{kPa})\end{array}$ & $\begin{array}{l}\text { Hydraulic } \\
\text { gradient } \\
(\mathrm{m} / \mathrm{m})\end{array}$ \\
\hline S1 & 10 & 100 & 5 \\
\hline S2 & 10 & 100 & 20 \\
\hline S3 & 10 & 100 & 20 \\
\hline S4 & 10 & 100 & 60 \\
\hline S5 & 10 & 100 & 100 \\
\hline S6 & 10 & 100 & 110 \\
\hline S7 & 10 & 100 & 140 \\
\hline S8 & 10 & 150 & 20 \\
\hline S9 & 10 & 150 & 60 \\
\hline S10 & 10 & 150 & 100 \\
\hline $\mathrm{S} 11$ & 10 & 150 & 140 \\
\hline $\mathrm{S} 12$ & 10 & 150 & 140 \\
\hline $\mathrm{S} 13$ & 10 & 200 & 5 \\
\hline S14 & 10 & 200 & 10 \\
\hline S15 & 10 & 200 & 20 \\
\hline S16 & 10 & 200 & 20 \\
\hline S17 & 10 & 200 & 20 \\
\hline S18 & 10 & 200 & 40 \\
\hline S19 & 10 & 200 & 60 \\
\hline S20 & 10 & 200 & 80 \\
\hline S21 & 10 & 200 & 90 \\
\hline S22 & 10 & 200 & 100 \\
\hline S23 & 10 & 200 & 140 \\
\hline S24 & 10 & 250 & 90 \\
\hline S25 & 10 & 250 & 100 \\
\hline S26 & 20 & 100 & 20 \\
\hline S27 & 20 & 100 & 60 \\
\hline S28 & 20 & 100 & 100 \\
\hline S29 & 30 & 100 & 100 \\
\hline S30 & 30 & 100 & 100 \\
\hline
\end{tabular}

as continuous. The substantial variations of the maximum erosion rate observed here can be represented using the following power law:

$$
q_{s \max }=12\left(10^{0.02 i}-1\right)
$$

where the number of tests $N=8$; and the correlation coefficient $r=0.999$. The curve analysis described by Eq. (7) allows us to examine some elements concerning the critical gradient. The maximum erosion rate values are plotted according to a logarithmic scale (Fig. 8). For the smallest erosion rate value achieved using the optical sensor, the critical gradient is equal to $5 \mathrm{~m} / \mathrm{m}$. From Fig. 8, the maximum erosion rate is given by

$$
q_{s \max }=16.6\left[10^{0.02(i-5)}-1\right] \quad(N=8, r=0.999)
$$

The small difference between both expressions and the global curve shape reveals the difficulty in identifying the critical gradient value precisely, all the more so since it also depends on the accuracy of the experimental setup used. Because the material resistance to erosion depends on the material's inherent characteristics, clay content effects were also examined. Fig. 9 presents the maximum erosion rate as a function of the clay content. The values used here have been obtained with samples which have been consolidated at $100 \mathrm{kPa}$. 


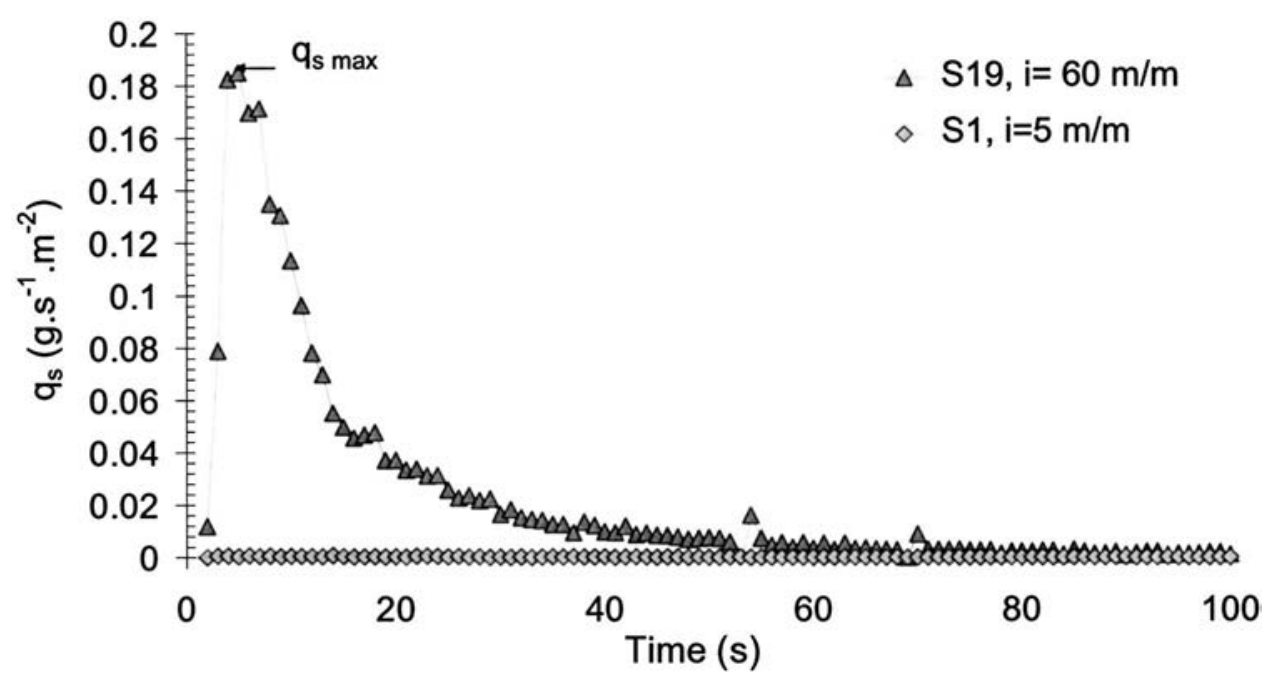

Fig. 6. Typical time-mass flow curve $\left(10 \%, \sigma_{3}=200 \mathrm{kPa}\right)$

These tests show that, depending on the hydraulic gradient, the erosion of the soils studied decreases as a function of the clay content according to

$$
\begin{aligned}
& \text { for } i=20 \mathrm{~mm}: \quad q_{s \max }=-0.06 \% \text { clay }+1.28 \quad(N=3, r=1) \\
& \text { for } i=60 \mathrm{~mm}: \quad q_{s \max }=-0.13 \% \text { clay }+2.85 \quad(N=2) \\
& \text { for } i=100 \mathrm{~mm}: \quad q_{s \max }=-0.17 \% \text { clay }+5.15 \\
& \qquad(N=4, r=0.996)
\end{aligned}
$$

In a general way, the erosion rate doubles when the clay content changes from 20 to $10 \%$.
We note that when the kaolinite content increases, the initial permeability decreases, causing the global flow within the sample to be falling. The decrease in the particulate water velocity $v_{p}$ can then be estimated as

$$
v_{p}=\frac{v_{m}}{n}
$$

with $v_{m}=$ flow velocity within the sample $(\mathrm{m} / \mathrm{s})$ and $n=$ porosity.

Darcy's law gives

$$
v_{p}=\frac{k \times i}{n}
$$

For a given hydraulic gradient and two kaolinite content values (10 and 30\%)

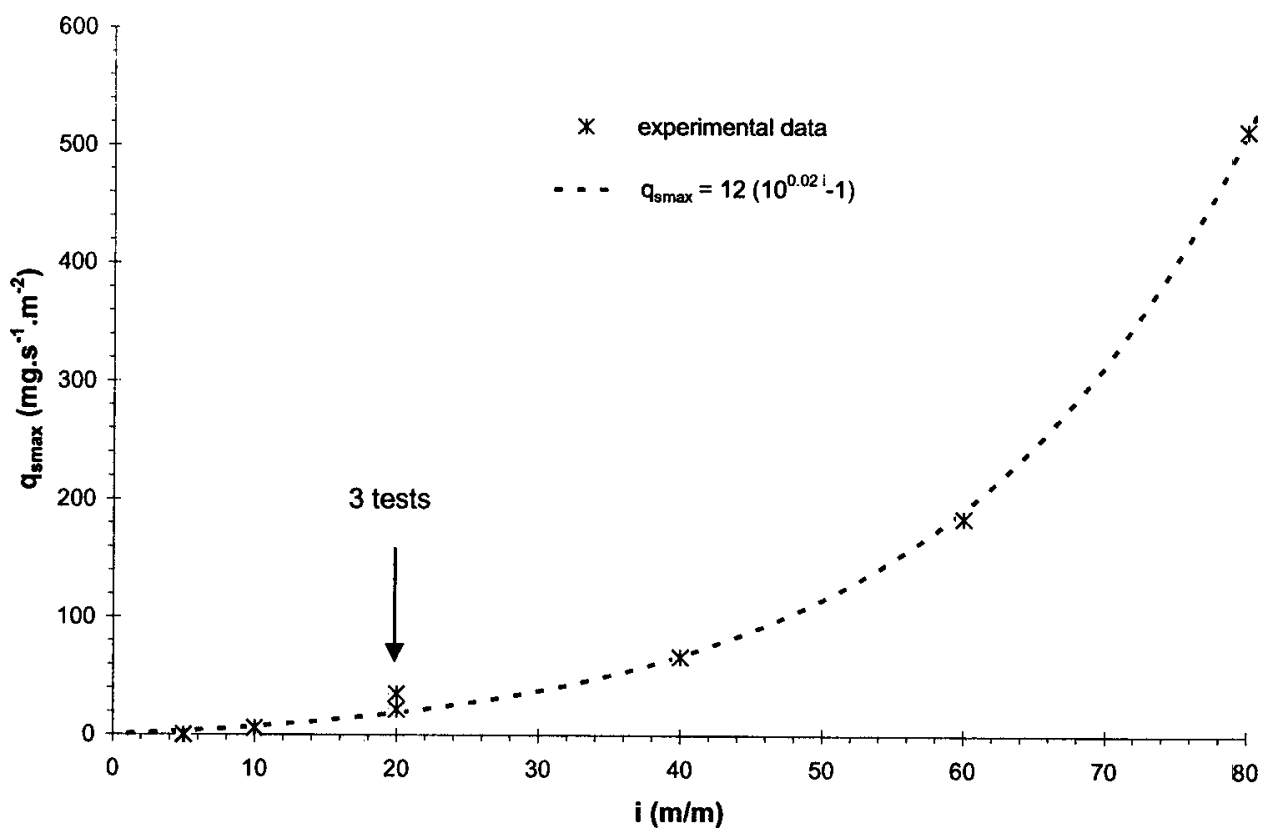

Fig. 7. Influence of the hydraulic gradient on clay erosion ( $10 \%$ clay content, $\left.\sigma_{3}=200 \mathrm{kPa}\right)$ 


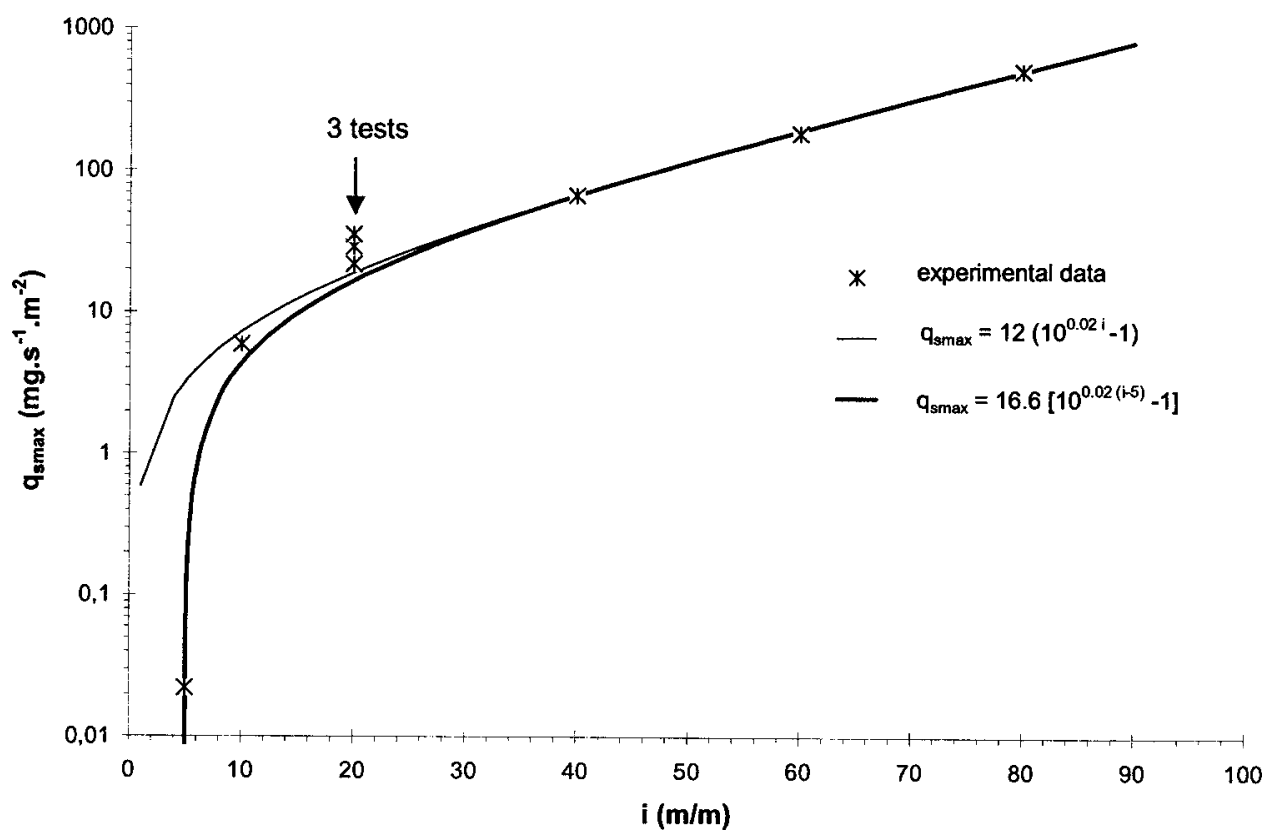

Fig. 8. Influence of the hydraulic gradient on clay erosion, logarithmic scale $\left(10 \%\right.$ clay content, $\left.\sigma_{3}=200 \mathrm{kPa}\right)$

$$
i=\mathrm{constant}=\frac{v_{p 30 \%} \times n_{30 \%}}{k_{30 \%}}=\frac{v_{p 10 \%} \times n_{10 \%}}{k_{10 \%}}
$$

Finally, with $n_{30 \%}=30 \%$ and $n_{10 \%}=33 \%, k_{30 \%}=1.5 \times 10^{-7} \mathrm{~m} / \mathrm{s}$ and $k_{10 \%}=2.5 \times 10^{-5} \mathrm{~m} / \mathrm{s}$, we obtain

$$
v_{p 30 \%}=0.0066 v_{p 10 \%}
$$

This solution shows that the particle velocity within sand/clay samples with a $30 \%$ kaolinite content is 150 times slower than with a $10 \%$ content. When the velocity decreases, the hydraulic shear stress generated by the flow within the samples also decreases and contributes to increase the internal erosion resistance.

With the intention of considering hydraulic gradient and porosity effects, the hydraulic shear stress is computed using Eq. (1). Fig. 10 represents the evolution of the maximum erosion rate according to the hydraulic shear stress for a confining pressure of $100 \mathrm{kPa}$.

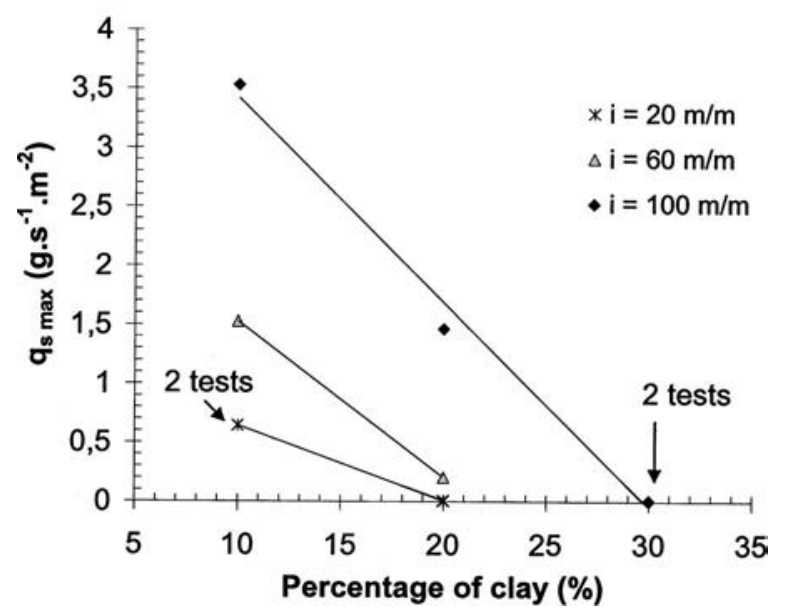

Fig. 9. Influence of the clay content and of the hydraulic gradient on clay erosion $\left(\sigma_{3}=100 \mathrm{kPa}\right)$
The correlation between the data is not linear as regards to clay content values. The critical hydraulic shear stress value for different clay contents, however, can be determined graphically: $\tau_{\mathrm{cr}}=0.13,0.23$, and $0.32 \mathrm{~Pa}$ for 10,20 , and $30 \%$ clay content values, respectively.

Because the initial porosity of a soil depends on soil consolidation, studying the effects of the confining pressure is essential.

For sand specimens subjected to odometer confinement conditions, Papamichos et al. (2001) observed that the maximum erosion rate increases with the applied axial pressure. The present tests, on the other hand, that were conducted under isotropic confinement with a $20 \mathrm{~m} / \mathrm{m}$ hydraulic gradient and a $10 \%$ clay content, reveal some opposite results (Fig. 11).

Depending on the hydraulic gradient value, the linear decrease of the maximum erosion rate according to the confining pressure is expressed as Eqs. (16) or (17)

$$
\begin{aligned}
& \text { for } i=20 \mathrm{~m} / \mathrm{m}: \quad q_{s \max }=-0.006 \sigma_{3}+1.256 \\
& \qquad \begin{aligned}
(N=6, r=0.9996) \\
\text { for } i=60 \mathrm{~m} / \mathrm{m}: \quad q_{s \max }=-0.013 \sigma_{3}+2.877 \\
(N=3, r=1)
\end{aligned}
\end{aligned}
$$

Such an evolution underlines the necessity to use a flexible cell to subject the samples to stresses as close as possible to reality.

The growth in the confining pressure and, therefore, in the material consolidation increases the interparticulate contact bonds and intensifies the internal erosion resistance. If we consider a portion of the sample at a given height, it is possible to demonstrate that the hydraulic gradient growth causes locally a rise in the pore pressure and, at constant confining pressure, a decrease in the effective stress. The increase in the hydraulic gradient here appears to have the same effects as a reduction in the sample consolidation. This observation, however, does not apply to the bottom part of the sample, where the pore pressure remains nil. 


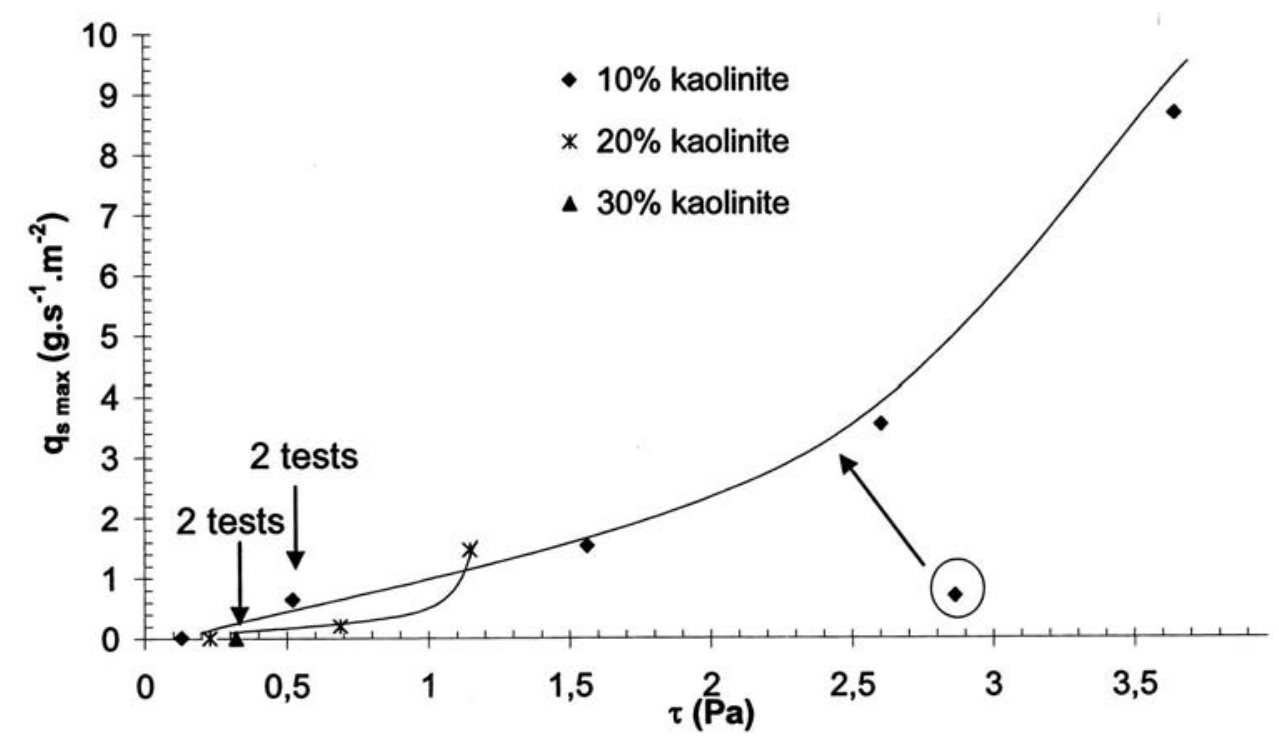

Fig. 10. Maximum erosion rate according to hydraulic shear stress and clay content $\left(\sigma_{3}=100 \mathrm{kPa}\right)$

In conformity with the previous procedure, the maximum erosion rate is represented according to the hydraulic shear stress for different confining pressure values (Fig. 12).

To obtain the same maximum erosion rate, the hydraulic shear stress has to increase as a function of the confining pressure. However, because no clear classification appears here, the expression of the hydraulic shear stress does not make it possible to consider the confining pressure effects on the maximum erosion rate accurately.

The result difference observed between the samples tested here and the Papamichos et al. (2001) specimens can be accounted for by many reasons: The characteristics of (1) the pressure first, which can be isotropic or axial; (2) the samples, which can be made of a sandy-clay mixture or composed of sand only; (3) the phenomena examined, which are interpreted to be suffusion or backward erosion; and (4) the sand grain angularity.

\section{Clay and Sand Erosion}

Considering two samples (S9 and S11) both with a $10 \%$ clay content and consolidated at $150 \mathrm{kPa}$. The first sample subjected to the action of a hydraulic gradient of $60 \mathrm{~m} / \mathrm{m}$ suffered some clay erosion, whose extent was measured using the optical sensor, and gave a clay eroded mass of $60 \mathrm{mg}$. Sample S11, on the other hand, subjected to a $140 \mathrm{~m} / \mathrm{m}$ hydraulic gradient, gave a weighed eroded mass (clay and sand) of approximately $40 \mathrm{~g}$ (Fig. 13).

The quantity of effluents achieved here (17\% of the sample initial volume) produces a substantial volume variation within the sample, which finally collapses, revealing then a significant change in the erosion mechanisms. Clay and sand particles are discharged from the soil downstream and along the upstream line through a backward erosion mechanism occurring within the sample.

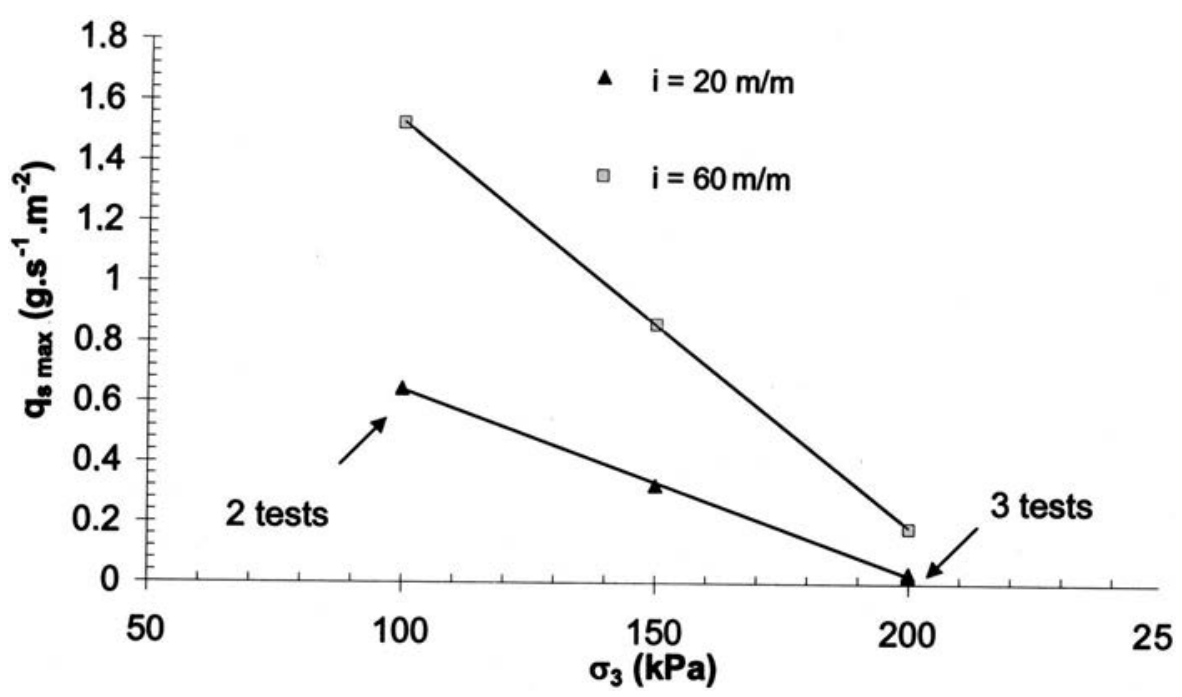

Fig. 11. Influence of the confining pressure on clay erosion (10\% clay content) 


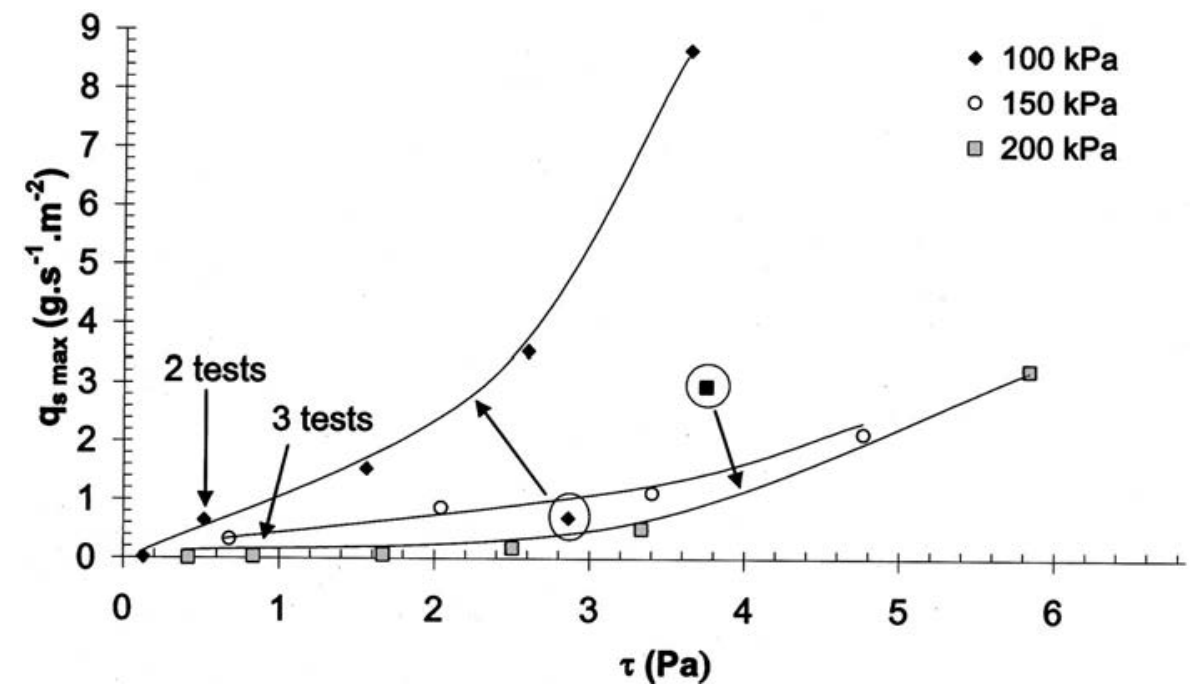

Fig. 12. Maximum erosion rate according to hydraulic shear stress and confining pressure (10\% clay content)

Fig. 14 shows the effects of the confining pressure on the maximum erosion rate (determined by weighing regarding sand erosion). This confirms that when the confining pressure rises, sand erosion within the samples tends to increase. These results demonstrate the significance of confining pressure effects on sample performances. It confirms the existence of a secondary critical gradient, from which both clay and sand transportation is initiated. This gradient depends on the confining pressure, on the clay content, and on the material.

If the hydraulic gradient remains below this backwards erosion critical gradient value, confinement tends to increase the sample resistance to suffusion. When the hydraulic gradient, on the other hand, is higher than this value, backward erosion begins.

The backward erosion increase, as a function of confining pressure, confirms the Papamichos et al. (2001) conclusions that were achieved on the basis of tests with specimens made of sand only.

\section{Conclusions and Perspectives}

Mechanisms responsible for internal erosion are many, evolutionary, and depend on different parameters. In the face of such com-

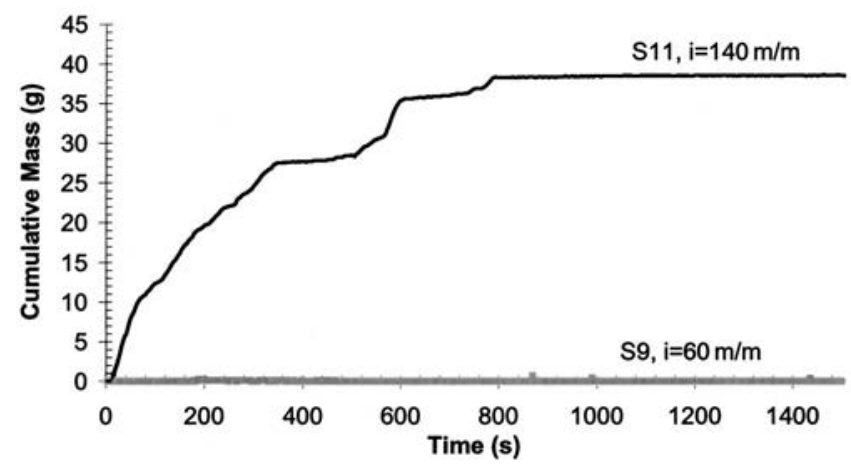

Fig. 13. Cumulative eroded mass versus time (Samples $\mathrm{S} 9$ and $\mathrm{S} 11$, $10 \%$ clay content, $\left.\sigma_{3}=150 \mathrm{kPa}\right)$ plexity, internal erosion initiation and development criteria found in the literature are closely dependent on the structure studied and, therefore, diverse.

New earth-structure recent failures reveal the inadequacy of the current criteria to assess internal erosion initiation and its development, and hence, the resulting variations in soil mechanical performances. Consequently, the design and development of a new experimental setup, which can be used for a test campaign that can systematically study the influence of parameters of concern here, appeared essential.

The experimental setup that was developed and is described in this paper can be used to saturate and consolidate samples made of sand and clay. The triaxial cells used in the setup have been modified to let the (static or dynamic) flow go through the core of the sample in a downward direction. Long-lasting tests are possible thanks to the automation of both the monitoring and the acquisition of the data. Moreover, the possibility to use three cells simultaneously makes it possible to reduce the time length of the test program. The internal erosion critical gradient can be assessed from the effluent's instantaneous optical analysis. In order to address internal erosion development, injection volume flow rates and obtained mass flow measurements are compared.

The erosion occurring within the clay fraction does not affect the particle size distribution nor the volume of the samples significantly. Permeability, only, decreases. The erosion mechanism concerned here is called suffusion. The impact of three different parameters on the initiation of suffusion were examined.

The rate of suffusion increases according to the hydraulic gradient. The study conducted to assess the suffusion initiation point gives a critical gradient on the order of $5 \mathrm{~m}$ per $\mathrm{m}$. This value, however, being highly dependent on the accuracy of the setup used and on the properties of the soil studied, is, therefore, not generally applicable. For other soils tested, the critical gradient was higher. The initial clay content significantly affects suffusion mechanisms; the maximum erosion rate doubles when the clay content changes from 20 to $10 \%$.

The material initial porosity is also an important parameter, which depends on the particle size analysis, on the one hand, and on the confining pressure, on the other hand. The suffusion maxi- 


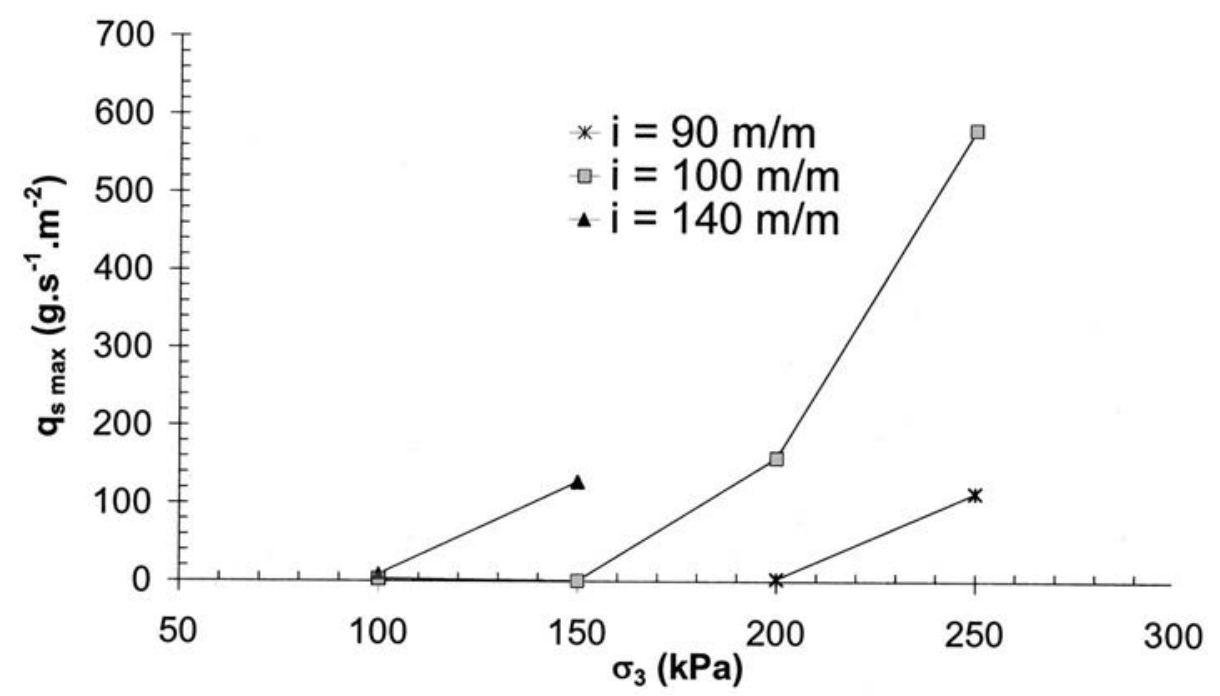

Fig. 14. Influence of the confining pressure on clay and sand erosion (10\% clay content)

mum erosion rate doubled when the confining pressure decreased from 150 to $100 \mathrm{kPa}$.

Because the hydraulic shear stress is a function of the above parameters, expressing it for the different tests appears essential. This approach makes it possible to identify the minimum stress levels, which depend on both clay contents and confining pressures, and below which suffusion will not occur for the soils tested:

For $\sigma_{3}=100 \mathrm{kPa}$ :

- $\tau_{\mathrm{cr}}=0.13 \mathrm{~Pa}$ with a $10 \%$ clay content;

- $\tau_{\mathrm{cr}}=0.23 \mathrm{~Pa}$ with a $20 \%$ clay content; and

- $\tau_{\mathrm{cr}}=0.32 \mathrm{~Pa}$ with a $30 \%$ clay content.

For $\sigma_{3}=200 \mathrm{kPa}$ and a $10 \%$ clay content: $\tau_{\mathrm{cr}}$ is approximately $0.42 \mathrm{~Pa}$.

These values are several orders of magnitude greater than those in the case of surface erosion experiments, referring notably to the results from tests done in rotating cylinders (Arulanandan and Perry 1983) or hole erosion test (Reddi et al. 2000). However, these values are four times smaller than those from the Reddi et al. (2000) measurements in the case of internal erosion experiments. The direct comparison of our results and the Reddi et al. (2000) measurements seems to be difficult for the moment. The resulting differences observed between the samples tested here, and the Ottawa sand+kaolinite mixtures tested by Reddi et al. (2000) can be accounted for as a result of several factors. First, the characteristics of the filter, that can either be open or a porous stone, may be responsible for these differences. The sand itself could also play a role, as grain sizes and grain angularities were different in our and their experiments.

When the hydraulic gradient increases above a secondary threshold value, the erosion of sand grains is suddenly initiated and evolves very quickly as particle backward erosion, causing the whole sample to collapse. This erosion mechanism can be described as backwards erosion, but may be due to cracking of the sample under high gradients and loads.

Backward erosion critical gradient values are very high, and, like suffusion, depend on both clay content and confinement stress. For clay contents higher than $10 \%$, no backwards erosion effect was observed, whereas with a $10 \%$ clay content, the backward erosion critical gradient is:

- $90 \mathrm{~m} / \mathrm{m}$ with $\sigma_{3}=200 \mathrm{kPa}$;

- $100 \mathrm{~m} / \mathrm{m}$ with $\sigma_{3}=150 \mathrm{kPa}$; and
- $140 \mathrm{~m} / \mathrm{m}$ with $\sigma_{3}=100 \mathrm{kPa}$.

These values confirm the complexity of confinement effects on internal erosion because, contrary to suffusion, confinement intensifies backward erosion. This experimental study opens up many new research prospects to address the problem of backward erosion development and quantization, while demonstrating the importance of confinement effects on internal erosion.

The performed tests point out that the processes measured here require higher gradients than are present in dams and dikes. This seems to show that for soils similar to those tested here, backward erosion and suffusion are probably not the preponderant phenomena that need to be considered for those structures.

\section{Acknowledgments}

Special thanks to Mr. Coué for his involvement in the production of the experimental device.

\section{Notation}

The following symbols are used in this paper:

$d_{50}=$ mean diameter;

$i=$ hydraulic gradient;

$K=$ intrinsic permeability;

$k=$ hydraulic Darcy's permeability;

$m=$ cumulated eroded solid mass;

$m_{k \text { out }}=$ kaolinite mass within the effluent;

$m_{w \text { inj }}=$ injected water mass;

$m_{w \text { out }}=$ water mass within the effluent;

$m_{w \text { sam }}=$ water mass within the sample;

$N=$ number of tests;

$n=$ porosity;

$q_{s}=$ erosive mass rate per unit surface;

$q_{s \max }=$ maximum erosion rate per unit area;

$q_{w}=$ injection flow;

$r=$ correlation coefficient;

$S_{\text {opt }}=$ kaolinite content determined by the optical sensor;

$s=$ sample cross-sectional area; 


$$
\begin{aligned}
U= & \text { relative variation of optical sensor terminal } \\
& \text { voltage; }
\end{aligned}
$$

$v_{m}=$ flow velocity;

$v_{p}=$ particulate water velocity;

$\gamma_{w}=$ volumic weight of water;

$\Delta L=$ sample height;

$\Delta P=$ pressure drop;

$\Delta P / \Delta L=$ average pressure gradient;

$\eta=$ dynamic viscosity;

$\sigma_{3}=$ confining pressure;

$\tau=$ hydraulic shear stress; and

$\tau_{\mathrm{cr}}=$ critical hydraulic shear stress.

\section{References}

AFNOR. (1994). "Essais à l'appareil triaxial de révolution." Rep. No. NF $P$ 94-074, Association Française de Normalisation.

Arulanandan, K., and Perry, E. B. (1983). "Erosion in relation to filter design criteria in earth dams." J. Geotech. Engrg., 109(5), 682-698.

Ayadat, T., Belouahri, B., and Ait Ammar, R. (1998). "La migration des particules fines comme approche d'explication du mécanisme de l'effondrement." Revue Française de Géotechnique, 83, 73-81.

Barakat, B. (1991). "Instabilité aux écoulements des milieux granulaires, aspects morphologiques et probabilistes." Ph.D. thesis, Ecole Centrale de Paris, France.

Bendahmane, F. (2005). "Influence des interactions mécaniques eau-sol sur l'érosion interne." Ph.D. thesis, Université de Nantes, France.

Camapum De Carvalho, J., Crispel, J., Mieussens, C., and Nardone, A. (1987). "La reconstitution des éprouvettes en laboratoire; théorie et pratique opératoire." Rapport de Recherche LCPC No. 145.

Daniel, D. E., Trautwein, S. J., Boynton, S. S., and Foreman, D. E. (1984). "Permeability testing with flexible-wall permeameters." Geotech. Test. J., 7(3), 113-122.

Foster, M., Fell, R., and Spannagle, M. (2000). "The statistics of embankment dam failures and accidents." Can. Geotech. J., 37, 1000-1024.

Kenney, T. C., and Lau, D. (1985). "Internal stability of granular filters." Can. Geotech. J., 22, 215-225.

Khilar, K. C., Fogler, H. S., and Gray, D. H. (1985). "Model for pipingplugging in earthen structures." J. Geotech. Engrg., 111(7), 833-846.

Lafleur, J., Mlynarek, J., and Rollin, A. L. (1989). "Filtration of broadly graded cohesionless soils.” J. Geotech. Engrg., 115(12), 1747-1768.

Monnet, A. (1998). "Boulance, érosion interne, renard. Les instabilités sous écoulement." Revue Française de Géotechnique, 82, 3-10.

Papamichos, E., Vardoulakis, I., Tronvoll, J., and Skjærstein, A. (2001). "Volumetric sand production model and experiment." Int. J. Numer. Analyt. Meth. Geomech., 25, 789-808.

Reddi, L. N., Lee, I., and Bonala, M. V. S. (2000). "Comparison of internal and surface erosion using flow pump test on a sand-kaolinite mixture." Geotech. Test. J., 23(1), 116-122.

Skempton, A. W., and Brogan, J. M. (1994). "Experiments on piping in sandy gravels." Geotechnique, 44(3), 440-460.

Tomlinson, S. S., and Vaid, Y. P. (2000). "Seepage forces and confining pressure effects on piping erosion." Can. Geotech. J., 37, 1-13.

Wan, C. F., and Fell, R. (2004). "Investigation of erosion of soils in embankment dams." J. Geotech. Geoenviron. Eng., 130(4), 373-380. 